DOI: https://doi.org/10.47405/mjssh.v5i12.603

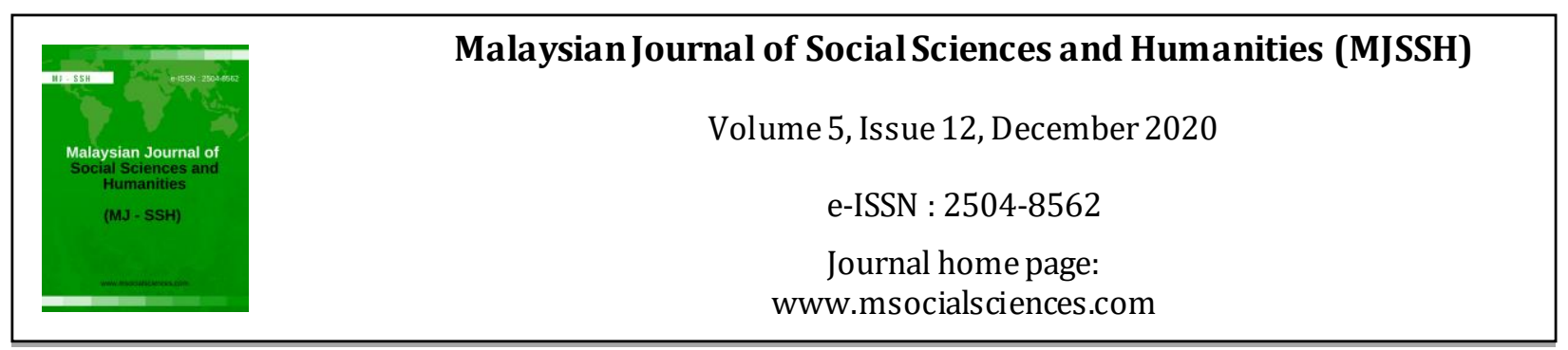

\title{
Pengetahuan tentang Perlembagaan dan Undang-undang dalam kalangan Pelajar Baharu di Universiti Malaysia Sabah (UMS)
}

\author{
Mohd Azri Ibrahim', Mohd Sohaimi Esa', Romzi Ationg1, Abang Mohd Razif Abang Muis', Budi Anto \\ Mohd Tamring ${ }^{1}$, Sirahim Abdullah ${ }^{1}$ \\ ${ }^{1}$ Pusat Penataran Ilmu dan Bahasa, Universiti Malaysia Sabah (UMS)
}

Correspondence: Mohd Azri Ibrahim (mohdazri@edu.my)

\begin{abstract}
Abstrak
Perlembagaan adalah satu dokumen yang sangat penting dalam sesebuah negara. Seseorang warganegara seharusnya memahami perlembagaan dan undang-undang serta menghayatinya bagi memastikan kehidupan bernegara lebih harmoni dan sejahtera. Masyarakat majmuk seperti di Malaysia seharusnya memahami perlembagaan dan juga lunas undang-undang. Ini akan dapat menjadi benteng daripada melakukan perbuatan yang bertentangan dengan perlembagaan dan undang-undang. Bagi memastikan individu dalam masyarakat berkenaan lebih berdisiplin dan beretika dalam bernegara, maka pemahaman perlembagaan dan undang-undang adalah sangat penting. Oleh itu ilmu-ilmu yang berkaitan dengan perlembagaan dan undang-undang seharusnya diajar dan dididik bagi memastikan setiap warganegara mempunyai nilai-nilai yang baik. Bagi memastikan kepentingan ilmu ini difahami dan dihayati oleh setiap masyarakat, maka kajian ini ingin meninjau dan menganalisis pengetahuan masyarakat terutamanya generasi muda terhadap perlembagaan dan undang-undang di Malaysia. Artikel ini mendapatkan responden dari kalangan pelajar universiti dalam menilai pengetahuan mereka tentang perlembagaan dan undang-undang sebagai skop terhadap kajian serta penulisan kertas kerja ini. Artikel ini juga menganalisis kepentingan perlembagaan dan undang-undang serta merumuskan dapatan kajian berdasarkan kepentingan ilmu tersebut terhadap mahasiswa. Adalah diharapkan agar dapatan kajian ini menyumbang kepada pemantapan keharmonian di negara ini.
\end{abstract}

Kata kunci: perlembagaan, undang-undang, masyarakat, mahasiswa

\section{Constitutional and Legal Knowledge among New Students in Universiti Malaysia Sabah (UMS)}

\begin{abstract}
The Constitution is an important document in any country. Citizens should understand the constitution and the law, as well as appreciate it to ensure harmonious and prosperous. A plural society like Malaysia should understand the constitution and are always abide by the law. This will hinder citizens form doing any that considered against both constitution and law. To ensure individuals within the society are more disciplined and ethical, understanding the constitution and laws is immensely valuable. Therefore, constitution and law must be taught in educational institutions to ensure each citizen has such values. To understand the importance of understanding and appreciating the constitution and law among the citizens, the study which this paper is based reviews and analyzes the understanding of constitution and laws among the citizens and particularly the youngster in Malaysia. This paper assessed the university students' knowledge of the constitution and law. It also analyzes
\end{abstract}


views among the university students about the importance of the constitution and the law as well as summarize the findings of the study. It is hoped that findings of the analysis help in pursuing harmonious in this country.

Keywords: constitution, legal, society, students

\section{Pengenalan}

Ayu (2019), Mohd Salleh (1997) dan Muhamed (1987) membincangkan tentang peranan Perlembagaan Persekutuan Malaysia sebagai agen dalam mengharmonikan perhubungan masyarakat majmuk di Malaysia. Interaksi awal dalam kalangan masyarakat majmuk yang mewakili setiap kaum yang dinamakan kontrak sosial menjadi titik permulaan kepada kewajaran pembentukan Perlembagaan Persekutuan Malaysia. Selain itu, terdapat peruntukan lain yang mendukung kepada permuafakatan kepelbagaian kaum di Malaysia iaitu peruntukan Perkara 153 Perlembagaan Persekutuan. Kewujudan Perlembagaan Persekutuan Malaysia menjadi ikatan yang bermakna dalam mensejahterakan hubungan masyarakat majmuk di Malaysia. Pengetahuan yang berkaitan dengan perlembagaan dan undangundang adalah asas untuk memenuhi keperluan dan matlamat meningkatkan nilai atau sikap positif dalam kalangan pelajar. Bagi mencapai matlamat ini, penekanan terhadap aspek pengetahuan, kefahaman kepentingan dan contoh-contoh peruntukan perlembagaan dan undang-undang adalah penting dan ia dapat memberi manfaat kepada pelajar. Bagi memastikan individu dan masyarakat lebih berdisiplin dan beretika dalam bernegara, maka pemahaman terhadap perlembagaan dan undangundang adalah sangat penting. Oleh itu, ilmu-ilmu yang berkaitan dengan perlembagaan dan undangundang seharusnya diajar dan dididik bagi memastikan setiap warganegara mempunyai nilai-nilai yang baik. Ini bagi memastikan kepentingan ilmu ini difahami dan dihayati oleh setiap masyarakat. Diharapkan setiap pelajar dapat memanfaatkan ilmu perlembagaan dan undang-undang ini bagi memastikan setiap ilmu yang dipelajari oleh pelajar dapat difahami dan akhirnya pelajar dapat menggunakan ilmu perlembagaan tersebut untuk kebaikan pelajar, masyarakat dan negara.

Beberapa kajian lepas berkaitan dengan Perlembagaan Malaysia telah dijalankan oleh para sarjana tempatan. Contohnya, kajian oleh Nazri Muslim bertujuan untuk mengenal pasti tahap pengetahuan, kefahaman dan penerimaan belia terhadap Perlembagaan Persekutuan Malaysia. Kajian tersebut melibatkan seramai 400 orang responden yang dipilih di sekitar Lembah Klang. Hasil kajian menunjukkan tahap pengetahuan, kefahaman dan penerimaan belia terhadap Perlembagaan Persekutuan adalah baik. Dapatan kajian juga menunjukkan faktor-faktor etnik, agama, aliran pendidikan sekolah rendah dan menengah sangat mempengaruhi tahap pengetahuan, kefahaman dan penerimaan belia terhadap Perlembagaan Persekutuan. Manakala sarjana seperti Salleh (1996), Nazri (2016) dan Mohd. Sohaimi et al. (2020) pula menjelaskan tentang penerimaan generasi muda masa kini terhadap persetujuan soal yang berkaitan dengan kontrak sosial seperti Perkara 153 dan keperluan terhadap peruntukan undang-undang. Melihat kepada kepentingan soal pengetahuan dan pemahaman warga belia berkaitan dengan isu-isu kenegaraan, maka kajian ini dijalankan untuk mengenal pasti pengetahuan tentang Perlembagaan dan Undang-undang dalam kalangan Pelajar Baharu di Universiti Malaysia Sabah (UMS).

\section{Metod Kajian}

Kajian ini secara umumnya menggunakan kaedah penyelidikan kuantitatif yang melibatkan set soal selidik yang menggunakan kaedah Google form yang telah dijawab oleh 160 orang pelajar baru iaitu pelajar tahun satu dan semester pertama di UMS pada Sesi 2020/2021. Soal selidik tersebut dianalisis dengan menggunakan analisis deskriptif. Pada masa, kajian ini juga melibatkan kaedah kualitatif iaitu sesi temu bual dan soal jawab menerusi platform WhatsApp dan menerusi portal online learning UMS. Dapatan kajian menerusi kaedah kualitatif akan dianalisis bersama-sama dengan dapatan kajian kuantitatif bagi mendapatkan satu rumusan berdasarkan aspek-aspek penting dalam kajian ini. 
Sebagaimana menurut Ahmad Tarmizi, Romzi \& Nurul Ain (2017) dan Madiyem et al. (2020), kaedah seumpama ini amat wajar dilakukan berikutan keperluan memastikan hasil kajian mengambil kira semua aspek yang diperlukan.

\section{Hasil Kajian}

Berdasarkan Jadual 1, pengkaji mendapati bahawa majoriti daripada responden mempunyai pengetahuan berkaitan dengan aspek kewujudan perlembagaan dan undang-undang. Hanya 5.6\% sahaja daripada keseluruhan responden mengatakan tidak tahu dan tidak pasti berkaitan dengan kewujudan undang-undang. Ini menunjukkan bahawa ada segelintir daripada responden masih tidak mengetahui atau mengambil cakna soal yang berkaitan dengan undang-undang. Bagi aspek yang berkaitan dengan rukun negara pula, hasil kajian menunjukkan bahawa 95\% mengetahui tentang perlembagaan dan undang-undang merupakan antara prinsip rukun negara manakala selebihnya mengatakan tidak tahu dan tidak pasti.

Jadual 1: Pengetahuan Terhadap Kewujudan Perlembagaan dan Undang-undang di Malaysia

\begin{tabular}{lccc}
\hline \multicolumn{1}{c}{ Soalan } & Ya & Tidak & Tidak Pasti \\
\hline Adakah anda tahu tentang kewujudan perlembagaan & 158 & 1 & 1 \\
persekutuan? & $(98.8 \%)$ & $(0.6 \%)$ & $(0.6 \%)$ \\
Adakah anda tahu tentang kewujudan undang-undang & 151 & 5 & 4 \\
persekutuan? & $(94.4 \%)$ & $(3.1 \%)$ & $(2.5 \%)$ \\
Adakah anda tahu bahawa aspek perlembagaan dan & 152 & 2 & 6 \\
undang-undang adalah salah satu prinsip Rukun Negara? & $(95 \%)$ & $(1.2 \%)$ & $(3.7 \%)$ \\
\hline
\end{tabular}

Jadual 2 pula memperincikan tentang dapatan kajian yang berkaitan dengan pengetahuan dan kepentingan ilmu perlembagaan dan undang-undang. Dapatan kajian menunjukkan bahawa kesemua responden mengakui bahawa perlembagaan dan undang-undang adalah penting kepada sesebuah negara. Manakala 98.8\% responden berpendapat bahawa sebagai pelajar atau masyarakat adalah sangat penting memiliki ilmu dan pengetahuan berkaitan dengan perlembagaan dan undang-undang. Manakala 95\% daripada responden mengakui akan mematuhi perlembagaan dan undang-undang. Bagi aspek untuk meningkatkan nilai tambah berdasarkan kemahiran insaniah, sebanyak $98.1 \%$ responden berpendapat bahawa ilmu perlembagaan dan undang-undang dapat meningkatkan kemahiran insaniah pelajar.

Jadual 2: Kepentingan Ilmu Perlembagaan dan Undang-undang Terhadap Pelajar atau Masyarakat

\begin{tabular}{|c|c|c|c|}
\hline Soalan & Ya & Tidak & Tidak Pasti \\
\hline $\begin{array}{l}\text { Adakah anda bersetuju bahawa perlembagaan dan } \\
\text { undang-undang adalah penting kepada sesebuah negara } \\
\text { seperti di Malaysia? }\end{array}$ & $\begin{array}{c}160 \\
(100 \%)\end{array}$ & - & - \\
\hline $\begin{array}{l}\text { Adakah anda bersetuju bahawa setiap pelajar dan } \\
\text { anggota masyarakat perlu memiliki pengetahuan asas } \\
\text { berkaitan dengan perlembagaan dan undang-undang? }\end{array}$ & $\begin{array}{c}158 \\
(98.8 \%)\end{array}$ & $\begin{array}{c}1 \\
(0.6 \%)\end{array}$ & $\begin{array}{c}1 \\
(0.6 \%)\end{array}$ \\
\hline $\begin{array}{l}\text { Adakah anda akan patuh dan akur dengan perkara- } \\
\text { perkara yang terkandung dalam perlembagaan dan } \\
\text { undang-undang? }\end{array}$ & $\begin{array}{c}152 \\
(95 \%)\end{array}$ & - & $\begin{array}{c}8 \\
(5 \%)\end{array}$ \\
\hline $\begin{array}{l}\text { Adakah anda berpendapat bahawa ilmu dan } \\
\text { pengetahuan yang berkaitan dengan perlembagaan dan } \\
\text { undang-undang dapat memberi nilai tambah kemahiran } \\
\text { insaniah kepada anda? }\end{array}$ & $\begin{array}{c}157 \\
(98.1 \%)\end{array}$ & - & $\begin{array}{c}3 \\
(1.9 \%)\end{array}$ \\
\hline
\end{tabular}

Temu bual dengan beberapa orang pelajar secara online learning dan WhatsApp juga digunakan dalam kajian ini, dan secara umumnya pelajar berpendapat bahawa ilmu pengetahuan berkaitan dengan perlembagaan dan undang-undang adalah penting dan sangat bermanfaat kepada mereka. Pelajar 
berpendapat bahawa ilmu pengetahuan yang berkaitan dengan perlembagaan dan undang-undang adalah sangat berguna kepada seseorang pelajar seperti ilmu yang berkaitan dengan hak asasi, pilihan raya, institusi negara dan perbuatan subversif serta undang-undang yang berkaitan dengan jenayah, rasuah. Mereka berpendapat bahawa ilmu sebegini akan dapat menjadi panduan kepada mereka dalam menjalani kehidupan sebagai pelajar dan bermasyarakat suatu hari nanti. Nilai-nilai murni seperti kepatuhan terhadap peraturan, kecintaan kepada diri, keluarga dan negara serta menghargai sesuatu yang dimiliki adalah antara nilai murni yang dapat diperoleh menerusi pembelajaran yang berkaitan dengan ilmu perlembagaan dan undang-undang.

Menurut seorang pelajar yang telah ditemu bual mengatakan bahawa "pengetahuan tentang peruntukan perlembagaan dan undang-undang adalah penting bagi dirinya dan pengetahuan saya terhadap institusi beraja dan sistem pemerintahan negara semakin baik dan pastinya ia berguna kepada saya sebagai seorang warganegara". Manakala menurut seorang lagi pelajar yang ditemu bual, mengatakan bahawa "saya memang berminat dengan ilmu yang berkaitan dengan perlembagaan kerana saya dapat mempelajari hal-hal seperti hak asasi, perundangan dan pilihan raya serta hal-hal lain, ini dapat menjadikan saya lebih mencintai negara kita". Berdasarkan huraian dan pendapat pelajar adalah jelas membuktikan bahawa akan kepentingan ilmu ini kepada pelajar.

Berdasarkan Jadual 3, dapatan kajian menunjukkan bahawa sebanyak $88 \%$ dan $80.1 \%$ pelajar atau responden mengatakan pernah belajar perkara-perkara yang terkandung di dalam perlembagaan dan undang-undang, manakala selebihnya iaitu sekitar $12 \%$ dan $19.3 \%$ mengatakan tidak pernah atau tidak pasti. Seorang pelajar yang ditemu bual mengatakan bahawa "saya berminat untuk mempelajari ilmu yang berkaitan dengan undang-undang rasuah dan pilihan raya supaya saya lebih memahaminya dan selaras dengan peruntukan perlembagaan dan undang-undang dan ianya dapat memberi manfaat kepada pengetahuan dan tingkah laku saya".

Jadual 3: Pembelajaran Ilmu Pengetahuan Perlembagaan dan Undang-undang di Malaysia

\begin{tabular}{lccc}
\multicolumn{1}{c}{ Soalan } & Ya & Tidak & $\begin{array}{c}\text { Tidak } \\
\text { Pasti }\end{array}$ \\
\hline Adakah anda pernah belajar perkara-perkara yang terkandung dalam & 141 & 6 & 13 \\
perlembagaan di Malaysia? & $88 \%$ & $3.7 \%$ & $8.1 \%$ \\
Adakah anda pernah belajar apa-apa undang-undang yang terdapat di & 129 & 6 & 25 \\
Malaysia? & $80.6 \%$ & $3.7 \%$ & $15.6 \%$ \\
\hline
\end{tabular}

Berdasarkan kepada Rajah 1 di bawah, didapati bahawa sumber maklumat pelajar atau responden bagi mendapatkan ilmu pengetahuan yang berkaitan dengan perlembagaan dan undang-undang ialah sekolah, media sosial dan TV atau radio. Sumber maklumat menerusi sekolah menyumbang sebanyak 96.3\% dan diikuti dengan media sosial sebanyak $78.1 \%$ dan sumber maklumat menerusi TV atau radio pula adalah sebanyak $48.1 \%$. Di samping itu juga, sumber maklumat lain adalah seperti keluarga dan surat khabar iaitu sebanyak $20 \%$ manakala ceramah dan rakan pula masing-masing sebanyak $19.4 \%$ dan $15.6 \%$.

Dapatan kajian berdasarkan sumber maklumat dan pengetahuan berkaitan dengan perlembagaan dan undang-undang secara umumnya memperlihatkan bahawa pendidikan dan pembelajaran di sekolah sangat penting bagi memperoleh ilmu pengetahuan dan maklumat-maklumat yang berkaitan dengan perlembagaan dan undang-undang di Malaysia. Begitu juga halnya dengan peranan dan pengaruh media sosial dalam arus perkembangan teknologi kini yang secara jelas memperlihatkan pelajar aktif menggunakan teknologi seperti smart phone, laptop atau gajet untuk mendapatkan sumber maklumat atau memperoleh sumber maklumat yang berkaitan dengan perlembagaan dan undang-undang. Oleh itu, adalah penting bagi sekolah untuk mengintegrasikan penggunaan alat telekomunikasi demi mempertingkatkan pengetahuan pelajar terhadap perlembagaan dan undang-undang. 
Rajah 1: Sumber Maklumat Berkaitan dengan Pengetahuan terhadap Perlembagaan dan Undangundang

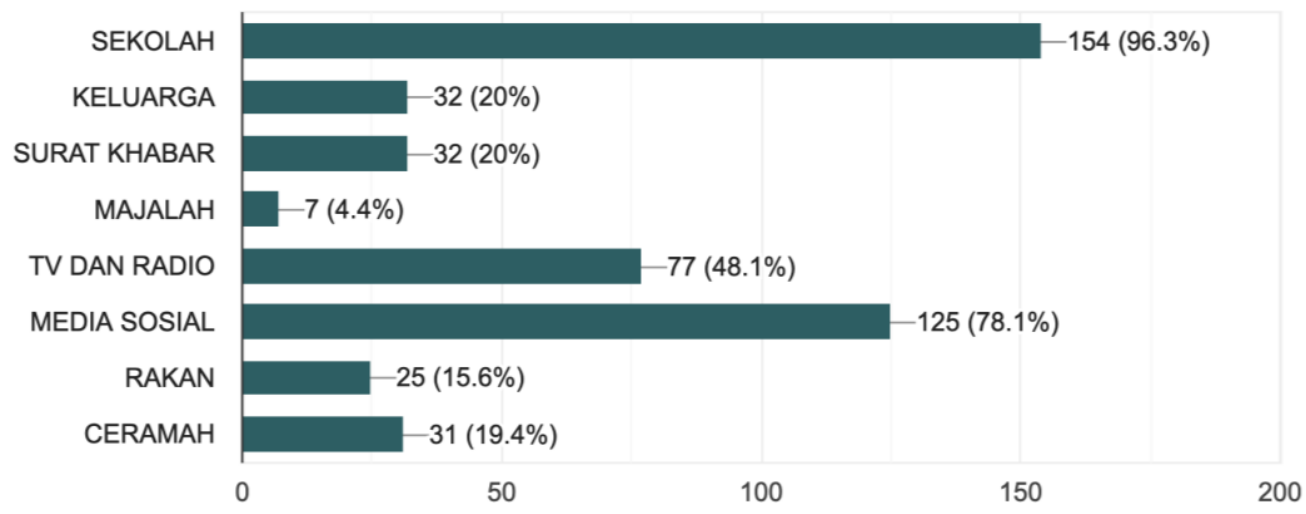

Rajah 2 di bawah menunjukkan dapatan kajian pengetahuan pelajar tentang contoh-contoh peruntukan dalam perlembagaan dan undang-undang di Malaysia. Dapatan kajian secara jelas memperlihatkan bahawa lima contoh-contoh peruntukan perlembagaan yang paling diketahui oleh responden ialah berkaitan dengan pilihan raya $(89.4 \%)$, kewarganegaraan $(84.4 \%)$, hak asasi $(77.5 \%)$, YDPA dan Majlis Raja-Raja (56.9\%) dan parlimen (47.5\%). Manakala bagi aspek yang berkaitan dengan undangundang pula, didapati bahawa Akta Pencegahan Rasuah Malaysia telah mendapat skor yang paling tinggi iaitu sebanyak 92.5\% dan diikuti oleh Akta Dadah Merbahaya (80.6\%), Akta Pengangkutan Jalan (74.4\%), Akta Universiti dan Kolej Universiti (53.8\%) dan Akta Suruhanjaya Multimedia dan Komunikasi (54.6\%). Hasil dari penelitian ini menjelaskan bahawa pengetahuan pelajar melibatkan peruntukan seperti pilihan raya dan akta yang berkaitan dengan rasuah adalah sesuatu baik. Antara faktor-faktor yang membolehkan pelajar mempunyai kesedaran tinggi akan peruntukkan yang dinyatakan di atas adalah kerana pelajar telah didedahkan dengan maklumat dan berita menerusi pendidikan di sekolah, media massa dan media sosial terhadap hal-hal yang berkaitan dengan pilihan raya dan rasuah.

Rajah 2: Pengetahuan Pelajar Berkaitan dengan Contoh Peruntukan Perlembagaan Persekutuan
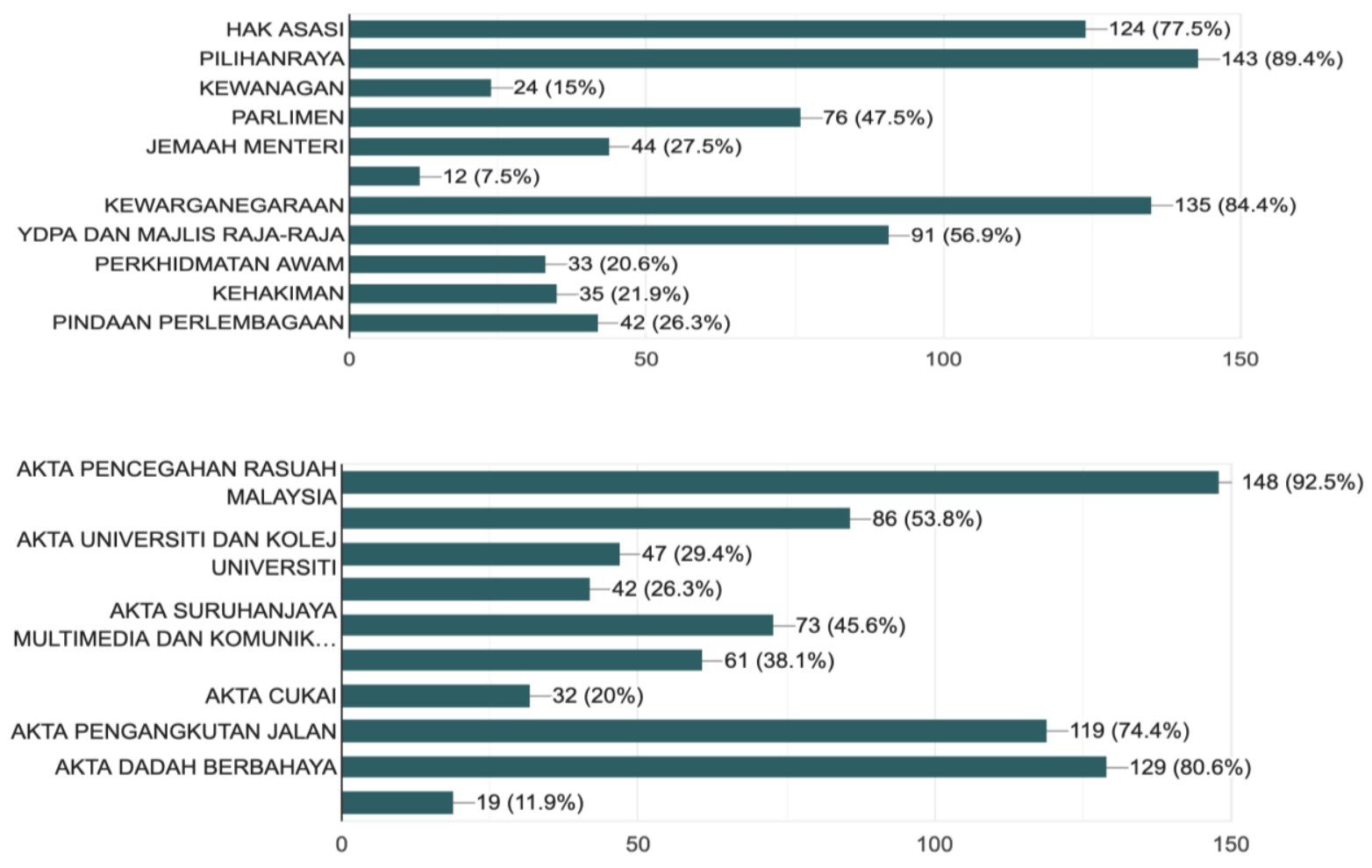
Dapatan kajian ini adalah sesuatu yang sangat baik dan positif terhadap pelajar dan negara. Ini membuktikan bahawa pelajar memperoleh pengetahuan dan pemahaman berkaitan dengan ilmu perlembagaan dan undang-undang akan dapat meningkatkan keperibadian dan sahsiah pelajar menjadi lebih unggul. Nilai dan peribadi pelajar yang baik adalah kunci kejayaan dalam pelajaran dan kerjaya serta masyarakat secara keseluruhannya pada masa depan. Sebagai contoh pengetahuan menerusi ilmu perlembagaan seperti pilihan raya (Bahagian 8) serta undang-undang seperti Akta Pencegahan Rasuah Malaysia. Pemahaman ilmu ini akan menjadi panduan kepada pelajar dan seterusnya menjadi pendorong kepada kehidupan yang lebih berintegriti. Ini penting kepada seseorang pelajar agar dapat menjadi pelajar dan anggota masyarakat yang dapat memberi sumbangan kepada keluarga, masyarakat dan negara. Oleh itu adalah penting ilmu perlembagaan dan undang-undang dalam mempersiapkan sahsiah pelajar yang unggul semasa mereka belajar di universiti.

\section{Kesimpulan}

Sebagai seorang pelajar dan merupakan generasi muda negara, adalah penting dan perlu bagi mereka untuk disemai dengan ilmu pengetahuan berkaitan dengan perlembagaan dan undang-undang. Ini bagi memastikan mereka menjadi pewaris kepimpinan negara dan masyarakat yang lebih baik. Oleh itu dengan harapan yang tinggi terhadap pelajar yang belajar di universiti, diharapkan mereka memanfaatkan ilmu, pengetahuan dan pemahaman terhadap perlembagaan dan undang-undang untuk kebaikan semua. Malaysia seharusnya diwarisi kepimpinan dan urus tadbir negara yang baik oleh mereka yang berilmu dan berintegriti tinggi. Diharapkan ilmu perlembagaan dan undang-undang yang disampaikan kepada pelajar hari ini dapat dimanfaatkan oleh pelajar untuk keperluan dan pembangunan negara pada masa depan.

\section{Rujukan}

Abdul Aziz Bari. (2003). Malaysian Constitution: A critical introduction. Kuala Lumpur: The Other Press.

Abdul Aziz Bari. (2001). Perlembagaan Malaysia: Asas dan masalah. Kuala Lumpur: Dewan Bahasa dan Pustaka

Abdul Aziz Bari. (2002). Majlis Raja-Raja: Kedudukan dan Peranan dalam Perlembagaan Persekutuaan. Kuala Lumpur: Dewan Bahasa dan Pustaka.

Ahmad Ibrahim. (1999). Perkembangan Undang-Undang Perlembagaan di Malaysia. Kuala Lumpur: Dewan Bahasa dan Pustaka.

Ahmad Tarmizi, A.R., Romzi Ationg \& Nurul Ain Zulhaimi. (2017). A paradigm shift in understanding mixed method research: A Malaysian perspective. Journal of Advanced Research in Social and Behavioural Sciences 9(1), 46-56

Ayu Nor Azilah. (2019). Faculty of Syariah and Law, Kolej Universiti Islam Antrabangsa Selangor. Journal of Muwafaqat, 2(1).

Azman Amin Hassan. (2005). Solving conflicts in a multicultural society: The case of Kampung Medan. Dalam Muhammad Kamarul Kabilan \& Zaharah Hassan. (eds.), Reading on Ethnic Relations in a Multicultural Society. Serdang: Penerbit UPM.

Madiyem Layapan, Romzi Ationg, Anantha Raman Govindasamy, Mohd Azri Ibrahim, Mohd Sohaimi Esa, Sirahim Abdullah \& Abang Mohd Razif Abang Muiz (2020). The Risks and benefits of Open Migration Policy in Asia-Pacific Region. Solid State Technology, 63(6), 776781.

Mohd Salleh Abas. (1997). Prinsip Perlembagaan dan Pemerintahan di Malaysia. Kuala Lumpur: Dewan Bahasa dan Pustaka.

Mohd. Sohaimi Esa, Romzi Ationg, Suraya Sintang, Abang Mohd. Razif Abang Muiz, Mohd Azri Ibrahim \& Sirahim Abdullah (2020). Youth Voluntary Organization, Leadership and Intergroup Relationship in Sabah, Malaysia: A Preliminary Discussion. Solid State Technology, 63(6), 722730 . 
Mohd Sohaimi Esa, Romzi Ationg, Siti Aidah Lokin, Sirahim Abdullah, Abang Mohd Razif Abang Muiz \& Mohd Azri Ibrahim. (2020). Linking Leadership Ethics and Intergroup Relationship through the Revision of Leadership Theories and Intergroup Relationship. Solid State Technology, 63(6), 742-752

Muhamed Suffian Hashim. (1987). Mengenal Perlembagaan Malaysia. Kuala Lumpur: Dewan Bahasa dan Pustaka.

Nazri Muslim. (2016). Kefahaman dan penerimaan belia terhadap perlembagaan persekutuan Malaysia. Institut Penyelidikan Pembangunan Belia Malaysia.

Romzi Ationg, Mohd. Sohaimi Esa \& Mohd. Azri Ibrahim (2020). Menyingkap Polemik Peralihan Kuasa Secara Luar Biasa Mengikut Perspektif Demokrasi Berparlimen. Malaysian Journal of Social Sciences and Humanities (MJSSH), 5(11), 43-53.

Romzi Ationg, Mohd Azri Ibrahim, Mohd. Sohaimi Esa \& Madiyem Layapan (2020). Analisis Pola Pengundian dan Senario Politik Semasa di Malaysia Era Pasca Pilihan Raya Umum (PRU) Ke-14 Berdasarkan Pilihan Raya Kecil P186 Sandakan, Sabah. Malaysian Journal of Social Sciences and Humanities (MJSSH), 5(5), 60-71.

Romzi Ationg, Mohd Sohaimi Esa, Abang Mohd Razif Abang Muiz, Mohd Azri Ibrahim, Suraya Sintang \& Sirahim Abdullah (2020). A Preliminary Discussion on the Need of Improving Leadership Ethics for Youth Voluntary Organization Development in Malaysia. Solid State Technology, 63(6), 731-741.

Salleh Buang. (1996). Sejarah Undang-Undang di Malaysia. Kuala Lumpur: Dewan Bahasa dan Pustaka. 